\section{Brandeis $\mid$ urear}

brandeis.edu/j-caste
CASTE: A Global Journal on Social Exclusion

Vol. 2 No. I pp. 202-218

April 2021

ISSN 2639-4928

DOI: $10.26812 /$ caste.v2i1.285

\title{
Journey with Rural Identity and Linguicism
}

\author{
Deepak Kumar'
}

\begin{abstract}
For a Dalit', especially from a rural background, it is not easy to survive in the higher education system in India because it is overwhelmingly dominated by the upper caste, class, and English-speaking people. It is not uncommon for Dalit learners like us to face multiple discrimination, and even exclusion in higher educational institutions. Intersectionality between these three factors abounds in institutions of higher learning. The transition from native language to English has not been an easy task for me, for in my educational journey, I have discovered that English is not just a language but also a commodity. It is becoming increasingly easy for economically well-off people to acquire education in English and dominate the spheres of educational institutions in India. They are usually considered as knowledgeable and intellectual persons. On the other hand, Dalit students also want to take education in English but, most of them are not able to do so because of their caste background and rampant discrimination. This study is based on my own experience and fieldwork at the University of Delhi through a semi-structured questionnaire.
\end{abstract}

\section{Keywords}

linguicism, English, Dalit, language discrimination, caste, intersectionality

\section{Introduction}

Language plays a significant role in speech, understanding, and communication which is crucial in acquiring and producing knowledge. Although English is regarded as the second official language in India, yet it is the dominant language in all spheres of education in contemporary times. India is a pluralistic society in terms of language, culture, religion, and region. But linguistically, English is

'Doctoral Candidate, Department of Political Science, Faculty of Social Science, University of Delhi Email ID: deepak.du@outlook.com

${ }^{1}$ Dalit is a term used for members of Scheduled Castes or former untouchables in India. 
a hegemonic language and its status is determined by various political, cultural, and social considerations. Furthermore, it also serves as a major tool to regulate power relations between English-medium students and non-English-medium students. In higher educational institutions, English is a major limitation for majority of the students, especially those with non-English-medium backgrounds and they feel excluded from the spheres of knowledge. Students from English-medium background enjoy certain power over their vernacular-medium counterparts both inside and outside the classrooms. Although, vernacular-medium students possess equal rational faculty but due to the conscious behaviour of the 'elite' English-medium groups (read students / teachers, etc.), vernacular-language-medium groups feel unwanted and unsuitable in the group relational contexts in most campuses. On account of these factors, such students remain submissive and are excluded from the so-called democratic and equal space.

When I was selected for post-graduation in the Political Science department of the University of Delhi, I was under the impression that it would be easy to survive in one of the country's prestigious universities. But I was woefully wrong! Before joining the University, I completed graduation in Hindi medium right from the elementary stage. My academic journey has been very challenging. After completing matriculation (secondary level) I worked as a domestic help for a while but was fired when I sought some extra free time from my employers to study. But my keenness to study more brought me to the national capital where I picked work as a roadside daily wager. However, despite all difficulties, my desire to study did not dim. Sometimes I worked as a fruit seller to sustain and pay for my education. Thus, I completed my graduation through distance mode of learning and then took admission as a regular Masters' student in the Political Science department. I went on to complete Master in Philosophy and am now pursuing Doctor of Philosophy. Only after entering the campus I realized why students and research scholars like me face multiple discriminations in different places; particularly when a learner from the Dalit community aspires to pursue higher education. Earlier, I used to think that discrimination in higher educational institutions based on language, caste, class, gender, race, region, and religion was a myth but after experiencing it firsthand I understood the grim reality of it.

As a student of post-graduation, my situation was very challenging because so far my medium of instruction had been Hindi, and the University was inundated with English-speaking students and teachers inside and outside the classrooms. All the students like me, who had vernacular language as their medium of instruction earlier faced similar fate in every sphere of this so-called democratic space. I also found that most of the non-English-medium students are from the Dalit community. Why do a majority of Dalit students hail from vernacular-medium schools? There is a relation between caste and economy, and we have to understand the politics of language in the context of acquiring knowledge. Michel Foucault described knowledge as a powerful tool to dominate others; and in academia, this power has always been exercised on the vernacular population through a different mechanism.

The social psychology of language perspective takes language into account along with its traditional justification. The social and communicative processes among 
various groups are determined by language and that results in discrimination, which produces the language-power relationships in multiple spheres. Therefore, different aspects of discriminatory practices based on linguistic differences pose certain crucial questions. In this context, this paper provides broader insights into the usage of language problems as a medium of instruction inside and outside the classroom, particularly through the researcher's own experience and of students from University of Delhi through collected data. This language problem is, somewhat, related to caste, class, and gender. This paper also provides insights into, how and in what ways does the language barrier create a binary between teacher-student, student-student, etc., and how the usage of one language as a medium of instruction dominates other languages in the classroom and influences students' lives in multiple ways.

The elitist status of one language in classrooms creates barriers for the overall acquisition of knowledge and development thus leading to a hiatus and disjuncture between the two groups. Being the predominant medium of instruction in higher educational institutions, English does not just cripple the essence of diversity it also acts as the hegemony of the 'elite' (English-speaking) group over the other (nonEnglish speaking). This can be seen as a strategy of the privileged caste, class, and gender that excludes the vast majority of students from the learning process.

\section{Multilingualism and the Medium of Instruction}

Language serves as a particular identity for a nation and even a marker for drawing boundaries and nationalism. The multilingualism of European countries is distinct from the multilingualism experienced in India, which is home to many indigenous / ethnic languages. Many European countries have one or two languages that are widely used in different domains whereas in India, we often see the use of different languages in different domains in daily life.

Most of the people in India are bilingual or multilingual. It is not uncommon to see the use of mother tongue at home, regional language at the market place, Sanskrit for religious activity and English in offices and for inter-state and international communication. Mohanthy quoted Bhatiya and Ritchie that ' $[\mathrm{m}]$ ultiple languages and multiple language identities are defining features of Indian bilingualism that reveal the dynamics of language usage and a constant negotiation of identity' (Mohanty, 2009, p. 264). Often, language users in India are more flexible and widen their identity beyond usage of a particular kind of language. Consequently, they become multilingual in nature.

Multi/bilingualism is maintained by communities in daily life interactions. In India after every ten miles, a new terrain shows the existence of diversity; that witness profound changes in accent and meaning of the language. Nevertheless, the communication is not broken, rather it is continuous. It needs to be understood that language and dialect are different in nature. Language is a medium or tool to communicate and share thoughts, ideas, emotions, expressions, and so on. The method of sharing is based on certain rules and regulations, systematic, gestures that convey to understand the meaning within inter or intra group or community. It is also shared through the written format. Languages have their own script to present themselves. 
Standardization of a language is the process in which it involves grammar, spelling books, dictionaries, literature, etc.

Multilingualism is not a negative potency but a positive force. It is the character of Indian society. Mother tongue always helps to understand the emotional, psychological, and intellectual situation of the member of their community and society. Ajit Kumar Mohanty (2009) argues that when the mother tongue is healthily maintained along with bi/tri or multilingual at the individual and community levels, social, psychological, and educational benefits accrue to the minority groups. This is the importance of multilingualism in India. The leaping advantages of a society being multilingual are easy accessibility of knowledge to other cultural community, less communication problem, high cognitive level of the child, and increase in job opportunities. Indian multilingualism is neither conflicting nor does it pose any threat to individuals and communities; languages are accepted as necessary and positive aspects of the social mosaic, except in an exceptional condition. These features add up to making multilingualism a positive phenomenon. They also ensure that the languages fall into neatly arranged pieces of coexistence as 'the petals of the Indian lotus' (Mohanty, 2009 , p. 265). The Indian perception of multilingualism is well characterized by D. P. Pattanayak (1984, p. 82) as:

The dominant monolingual orientation is cultivated in the developed world and consequently two languages are considered a nuisance, three languages uneconomic and many languages absurd. In multilingual countries many languages are facts of life; any restriction in the choice of language use is a nuisance, and one language is not only uneconomic, it is absurd.

In a multilingual country, like India, one language or language uniformity is not relevant and eventually, it will create a huge factiousness. Uniformity of language or medium of communication is important but it is not a sufficient condition for economic progress. Also, economic development is not an important condition for the uniformity of language. Academicians and public intellectuals are advocating that language uniformity is a necessary condition in the process of modernisation. They also emphasise it for communicative ease within state to interstate, and outside India.

Most of the tribal and minority mother tongues have no place in the Indian educational system. The children who enter schools with these mother tongues are forced into a dominant language 'submersion' education with a subtractive effect on their mother tongues (Mohanty, 2009, p. 268). Domination of one language over the other will be very harmful not merely to the members but also to the entire society. When people do not use their mother tongue it gradually leads to its death. Death of any language means the death of identity and culture. The stance of mutual acceptance, mutual accommodation, complementary and preservative relationship between languages has not been affecting other language speakers. Gradually, English is becoming a more hegemonic language in higher educational institutions in India. The hegemony of English is affecting the students' academic performances. Features of Indian multilingualism have been obliterated by the dominant existence of English and it is identified as a 'killer language'2 in postcolonial India. Being a powerful language in India, it gained larger control over the outcomes of social activity. In the

${ }^{2}$ The term 'killer language' (attributed to Anne Pakir in 1991 regarding English) is widely used even if it might feel offensive to some. The British linguist David Graddol (Open University) 
colonial period, English education was meant for a socio-economic purpose. In the contemporary period, it has become a divisive tool resulting in the division of society into two categories, i.e. privileged and underprivileged, and learned and ignorant classes. The so-called public education provided through vernacular languages and the quality of this educational system is mostly poor. Therefore, the private education system that provides education in English gives some hope to most parents from lower caste, class background who are willing to send their children to such schools. English language has the dubious distinction of pushing regional and scheduled languages at the margin in every domain. Mohanty (2009) argues that under the new dynamics of the power relationship between languages, English has become a potent factor in the differential power equation. English has gradually degraded and displaced major Indian languages, including the national language, Hindi, from the mainstream into the position of weak language.

\section{The Medium of Instruction in Indian Universities}

The medium of instruction in educational institutions is an important factor in the learning process. It is directly connected with the students' thought process and social-political values. ${ }^{3}$ Every language has its own value and it is related to sociocultural norms. It paves the way to gain knowledge about a society and its politics. It is a basic requirement for the student through which they are able to acquire and enhance their knowledge. Despite being multicultural, English gradually becomes the dominant/popular language in multiple spheres, such as educational, social, political, and economic life. Most of the central universities, such as the University of Delhi, Jawaharlal Nehru University, and Hyderabad Central University, etc., have adopted English as a medium of education principally from the post-graduation level in most courses in Humanities, i.e. Economics, Sociology, Geography, Political Science, etc. For instance, a large number of students from vernacular-language backgrounds who get enrolled in the University of Delhi opt for Social Sciences and Arts while other courses like Science and Commerce are fully sought by English-educated students. Vernacular-medium students who get low percentage in their senior secondary school (qualification for undergraduate courses) mostly seek enrolment in social sciences. Social Science courses are not considered as valuable subjects as these are not more employment-oriented as compared to other subjects. Moreover, the field of social sciences is also influenced by English-medium students who are able to acquire knowledge and enhance their capabilities sooner than vernacular-medium students thus relegating them to the background. Now, the state and citizens believe that English is the key to achieve betterment of life. In this scenario, linguistic and economically underprivileged students become more deprived of learning spaces (Table 1).

has mentioned 'English as a killer language' as subtitle in his article which was published in 1996. Tove Skutnabb-Kangas also mentioned it in her book in 2000.

${ }^{3}$ Social-Political Value is defined in terms of medium of instruction and its status in a particular society. In the precolonial period, Sanskrit and Arabic were considered socially and politically valuable languages. In the colonial period and now in independent India, English has become more socially and politically valuable in comparison to other indigenous languages. At present, English is the dominant medium of instruction in the central universities. This poses a huge challenge for those vernacular-language background students who want to gain enrolment in such institutions. 
Table I: Composition of students' economic backgrounds in University of Delhi $(\mathrm{N}=80)$

\begin{tabular}{|c|c|c|c|c|c|c|c|c|}
\hline \multirow[b]{2}{*}{$\begin{array}{l}\dot{\mathbf{z}} \\
\dot{v}\end{array}$} & \multirow[b]{2}{*}{ Discipline } & \multicolumn{6}{|c|}{ Economic Background of Students (Parents) } & \multirow[b]{2}{*}{ Total } \\
\hline & & 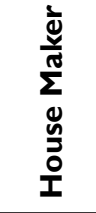 & 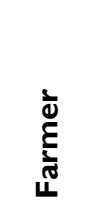 & 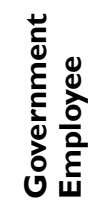 & $\frac{\mathscr{y}}{\stackrel{\Xi}{\bar{n}}}$ & 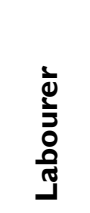 & 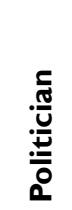 & \\
\hline 1 & $\begin{array}{l}\text { Political } \\
\text { Science }\end{array}$ & 06 & 08 & 13 & 05 & 08 & 01 & 41 \\
\hline 2 & History & 00 & 03 & 08 & 00 & 01 & 00 & 12 \\
\hline 3 & Social Work & 01 & 01 & 03 & 00 & 00 & 00 & 05 \\
\hline 4 & Economics & 02 & 00 & 06 & 01 & 02 & 00 & II \\
\hline 5 & Sociology & 00 & 00 & 05 & 00 & 00 & 00 & 05 \\
\hline \multirow[t]{2}{*}{6} & Geography & 00 & 01 & 04 & 01 & 00 & 00 & 06 \\
\hline & & $\begin{array}{c}09 \\
(11.3)\end{array}$ & $\begin{array}{c}13 \\
(16.3)\end{array}$ & $\begin{array}{c}39 \\
(48.8)\end{array}$ & $\begin{array}{c}07 \\
(8.8)\end{array}$ & $\begin{array}{c}11 \\
(13.8)\end{array}$ & $\begin{array}{c}01 \\
(1.3)\end{array}$ & $\begin{array}{c}80 \\
(100)\end{array}$ \\
\hline
\end{tabular}

Source: Researcher's field survey at University of Delhi

Note: Figures in parentheses are in per cent

According to Sukhadeo Thorat (2013) 'lower percentages of students are using Hindi and state languages as their medium of instruction for education. In fact, the share of student using English as a medium of instruction is nearly double of that in rural areas.' A study shows that 76 per cent students of Dr. B. R. Ambedkar University Delhi from government schools face problem with English as the medium of instruction. This study shows that caste and class also matter in the usage of language as a medium of instruction in academia. This survey report noted that,

The purpose of such a survey is to remind students, professor and the administration that the question of language is extremely sensitive, pervasive and complex. Within this, poor, Dalit, Bahujan, Adivasis and women students are particularly disadvantaged on account of problems with basic English language skills. This creates a sense of deficiency and inferiority amongst them within the campus. Thus, it is evident that the question of language is a question of social justice. (Indian Express, 2017)

The report clearly states that the problem of language is not just about the medium of communication and instruction; rather it is related to promoting social justice. It is the responsibility of the state and other institutions that they ensure quality and equal education to all, whether the people belong to different castes, classes, or even gender. It must provide all the necessary facilities for acquiring and producing knowledge. In contemporary India caste, gender, and economic background determine the accessibility to education. The educational system is broadly divided into two forms: vernacular-medium and English-medium. In order to explore why educational systems have been divided one needs to understand the quality of education that the public (government) schools provide through education in vernacular medium in comparison to private educational institutions that provide education in English medium. It is always considered that private schools provide quality education just because of 
their English language teaching. But it is a myth that only learning through English contributes to knowledge acquisition.

\section{The Medium of Instruction in the Classroom}

The medium of a language that is used inside the classroom for instruction by the teacher is a very important factor to understand equity and discrimination (Ahmad, 2013). It is an integral part of every classroom at multiple levels of the educational system. It determines the relationships between student-teacher, student-student (peer group relations) and student-content. Categorically, language plays an important role in teaching and learning situations, not only as the subject taught in schools but also, as the vehicle through which information is shared between the learner and the teacher (Olagbaju and Akinsowon, 2014). Communication in the classroom based on mother tongue is more beneficial for students as it generates interest in the subject, increases their confidence, and motivates them towards the learning process. It helps to build a cognitive power that is related to the mental process of judgement, reasoning, and perception. According to A. K. Dasgupta (1967), 'the medium of instruction at all stages of (a) student's education should be in his mother tongue - a language in which he has spoken naturally and spontaneously and through which he has seen and felt the world since his childhood.'

In the Indian context 'multilingual classroom' is good for students because the hegemony of one language over the other languages affects the life condition of vernacular-medium students. The official language or the primary language of the country doesn't need to be used as the medium of instruction (Ahmad, 2013). It is possible that the official language may be different from students' native or vernacular languages. To express their knowledge and enhance their thinking capacity about any subject matter, language is an important factor. Multilingualism or bilingualism in the Indian education system or classroom can be seen, when some students read, listen to lectures in one language, and write examinations in other languages. In the Indian context, most of the students read, listen to lectures accessing library in English medium, and write examinations in vernacular mediums. This kind of paradox is not encountered by English-medium students. On the basis of language, such inequality assumes the feeling of discrimination among the students in the classroom and the university system.

Linguistic discrimination is commonly applied in Indian educational institutions by different sections formally or informally by English-medium teachers and students. The phenomenon of language discrimination is also known as Linguicism. ${ }^{4}$ It happens not only in India but also in other countries of the world, such as Tanzania, Hong Kong, and South African countries.

There is a conflict between the medium of instruction within and outside the classroom. However, medium of instruction is very much important in classroom interaction and it involves behaviours where individuals and groups directly influence each other. While this can happen in many social settings, it can also be of great value in the teaching-learning process. Consequently, scholars have considered interaction

${ }^{4}$ The term Linguicism had been coined by Linguist Tove Skutnabb-Kangas in 1980s. She defined Linguicism as 'ideologies and structures that are used to legitimate, effectuate and reproduce an unequal division of power and resources between groups which are defined on the basis of language.' 
as an important factor for effective teaching and learning to take place (Ngussa, 2017, p. 4). When a teacher goes to teach and deliver the lecture in the classroom, his/her medium of lecture influences the students' interest in the lecture/topic. When teachers deliver a lecture in English to non-English background students, then the student cannot fully understand the topic/subjects. Apart from lectures, reading materials (Table 2) and other sources are also available predominantly in English. This approach reflects that one group has been more privileged over the other groups. These dichotomies in the classroom have a great impact on examination and knowledge outcomes.

Table 2: Language of reading materials in the classroom and library

\begin{tabular}{|c|c|c|c|c|c|c|c|c|c|c|c|c|c|}
\hline \multirow{3}{*}{$\begin{array}{l}\dot{0} \\
\dot{z}\end{array}$} & \multirow{3}{*}{$\begin{array}{c}\text { Sources of } \\
\text { Knowledgel } \\
\text { Learning in } \\
\text { the classroom } \\
\text { has been } \\
\text { available or } \\
\text { provided }\end{array}$} & \multicolumn{9}{|c|}{ Opinion on availability resources Medium } & \multirow{2}{*}{\multicolumn{3}{|c|}{ Total }} \\
\hline & & \multicolumn{3}{|c|}{ MA } & \multicolumn{3}{|c|}{ M.Phil. } & \multicolumn{3}{|c|}{ Ph. D } & & & \\
\hline & & 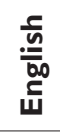 & $\begin{array}{l}: \overline{0} \\
\stackrel{\bar{x}}{\underline{x}}\end{array}$ & 官 & 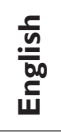 & 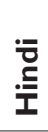 & 롱 & $\begin{array}{l}\frac{5}{\underline{n}} \\
\frac{.0}{60} \\
\frac{\omega}{\omega}\end{array}$ & 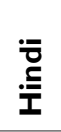 & 占 & 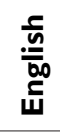 & $\begin{array}{l}\text { :0 } \\
\text { 竞 }\end{array}$ & 今ٌ \\
\hline $\mathrm{I}$. & $\begin{array}{l}\text { Lectures in the } \\
\text { classroom and } \\
\text { Instruction }\end{array}$ & 52 & - & - & 12 & - & $0 \mathrm{I}$ & 14 & - & 01 & 78 & - & 02 \\
\hline 2. & $\begin{array}{l}\text { Package } \\
\text { of Reading } \\
\text { materials }\end{array}$ & 52 & - & - & 13 & - & 00 & 15 & - & - & 80 & - & - \\
\hline 3. & $\begin{array}{l}\text { Interaction with } \\
\text { teacher\# }\end{array}$ & 44 & 01 & 06 & 09 & - & 04 & 11 & - & 04 & 64 & 01 & 14 \\
\hline 4. & $\begin{array}{l}\text { Interaction with } \\
\text { classmates/ } \\
\text { Hostel/Peer } \\
\text { Groups }^{\#}\end{array}$ & 16 & 15 & 20 & OI & 07 & 05 & 02 & 06 & 07 & 19 & 28 & 32 \\
\hline 5. & $\begin{array}{l}\text { Books Available } \\
\text { in the Library }\end{array}$ & 51 & - & 01 & 13 & - & - & 15 & - & - & 79 & - & 01 \\
\hline 6. & $\begin{array}{l}\text { Journals available } \\
\text { in the Library }\end{array}$ & 51 & - & 01 & 13 & - & - & 15 & - & - & 79 & - & 01 \\
\hline 7. & $\begin{array}{l}\text { E-Resources } \\
\text { available in the } \\
\text { Library }\end{array}$ & 52 & - & - & 13 & - & - & 15 & - & - & 80 & - & - \\
\hline
\end{tabular}

Source: Researcher's field survey at University of Delhi

\#One of the post-graduation students said that he interacted with teacher and students in his vernacular language during the Masters programme.

In the classroom context, interaction helps the teacher to receive feedback from the learners and discern the extent to which educational goals and objectives have been reached, hence, making necessary adjustments (Ngussa, 2017, p. 4). Sometimes bilingual teachers also teach students; the scenario is different from one language dominant classroom. Cutting across language mediums students participate without any hesitation in such an environment. The positive environment of the classroom strengthens students' confidence, makes the session interactive and promotes substantial engagement in the classroom. The influence of the language is also seen in dialogues, interactions, making of groups and friends inside and outside (Table 3) the classroom. 
The question is who are these students? And why are they not able to understand and use English as a medium of learning? Most of the students come from vernacularmedium schools either from rural or urban areas. Selection of medium of education or learning is dependent on their social and economic backgrounds. In contemporary times, everybody wants to send their children to English-medium school for a better education because of its reputation, and also, the market demand of this language.

Table 3: Language discrimination inside and outside the classroom and caste composition

\begin{tabular}{|c|c|c|c|c|c|c|c|c|c|c|}
\hline \multirow[b]{2}{*}{$\begin{array}{l}\dot{\mathbf{z}} \\
\dot{v}\end{array}$} & \multicolumn{2}{|c|}{ Caste Category } & \multicolumn{8}{|c|}{ Feelings due to Language Discrimination in Number and (Per cent) } \\
\hline & 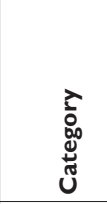 & 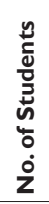 & 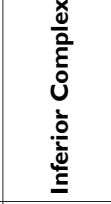 & 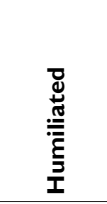 & 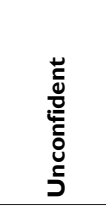 & 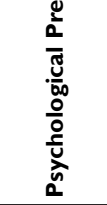 & 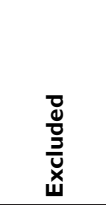 & 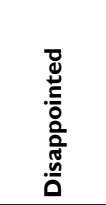 & 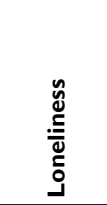 & 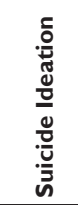 \\
\hline I. & SC & 24 & $16(66.7)$ & II (45.8) & $13(54.0)$ & $13(54.0)$ & $13(54.0)$ & $13(54.1)$ & $7(29.1)$ & $2(8.3)$ \\
\hline 2. & ST & 03 & I (33.3) & I (33.3) & $0(0.0)$ & I (33.3) & I (33.3) & $0(0.0)$ & $0(0.0)$ & $0(0.0)$ \\
\hline 3. & OBC & 26 & $16(61.5)$ & 7 (26.9) & $15(57.7)$ & $15(57.7)$ & $10(38.5)$ & II (42.3) & $8(30.8)$ & $2(7.7)$ \\
\hline 4. & Other & 27 & $10(37.0)$ & 7 (25.9) & $6(22.2)$ & $8(29.6)$ & $3(I I . I)$ & $4(14.8)$ & $3(11.1)$ & $0(0.0)$ \\
\hline & Total & 80 & $43(53.8)$ & $26(32.5)$ & $34(42.5)$ & $37(46.3)$ & $27(33.7)$ & $28(35.0)$ & $18(22.5)$ & $4(5.0)$ \\
\hline
\end{tabular}

Source: Researcher's field survey at University of Delhi

\section{The Hegemony of English Language in Indian Universities}

The meaning of hegemony in Greek is 'to lead'. Antonio Gramsci (1985) said that hegemony is established through consent and persuasion via the processes of leadership without force, leadership through legitimization, and leadership through consensual rule, which are the fundamental process of hegemony. Following Gramsci, Abolaji S. Mustapha mentioned Debra Suarez as he explained hegemony as a power relation between dominant and minority group, particularly the means by which the dominant group or the leading group secures its position (Mustafa, 2014, p. 59). In the context of language, there is a power relation between vernacular languages and English in India. The dominance of English is not only found in Indian educational institutions but across the globe. But, in a multilingual society like India, education in mother tongue or vernacular languages is made available till secondary level in governmentrun schools. When students get enroled in higher educational institutions for further studies, they have to face linguistic discrimination at different levels. In the classroom context of Indian central universities, both students and teachers from English medium are dominant. Indeed, the field of natural and professional sciences is almost all, possessed by the English medium, but the social sciences are also dominated by the English medium though a large number opts from vernacular-medium background. According to Sheila M. Shannon (1995), to maintain its dominant status, a language has to be associated with political, governmental, economic, and social domination and the consent of the people and emotions and psychology. Most of the teachers come from an English background; in contrast, an increasing number of students in the classroom 
come from the vernacular-medium background, for example, Hindi-medium students in the context of the University of Delhi. The strength of English-medium students is less than Hindi-medium students in the classrooms. But an English-medium student has participated more in the classroom because of their comfortability in the language. Shannon (1995) argues that,

The speakers of languages take on the prestigious or devalued characteristics of their languages. Thus, the speakers of dominant languages assume a prestigious status and are perceived as such. Conversely, minority languages speakers take on the burden of an inferior status and are so perceived. In terms of the nature of linguistic hegemony, this situation is not static.

Several factors contribute to the increase in the status of the English language in different contexts around the world. These are: uniformity of the textbook, language usage by higher officials, spread of English as a medium of communication across the world, and priority given to English by higher educational institutions. State machinery like the judiciary, bureaucracy, and other administrative and academics cutting across disciplines and regions are accepting English unconditionally.

Yan Guo and Gulbahar H. Beckett (2012, pp. 58-59) argue that the increasing dominance of the English language is contributing to neocolonialism by empowering the already powerful and leaving the disadvantaged further behind, an issue that needs attention. In the Indian context, this argument is appropriate because in the colonial period, only the upper caste, class, and males dominated the educational sphere. Even among these categories, education was restricted only to those who were educated already; other people were not able to access education in any other medium. When the question arises, who receives an education in the English medium, it becomes a serious problem. Those who were educated in the English medium in the colonial period, possess a special status to date. In the aftermath of independence, the Indian constitution assured education for all. However, it subsequently failed to hold its promise because education through the English medium was not accessible to a vast majority of population. Such unequal access to education has divided society into two groups: those studying in vernacular medium and others in English medium. The English-medium people are more powerful, considered intellectual and knowledgeable, socially, and politically empowered in comparison to vernacular-medium people. Consequently, vernacular-medium students feel marginalised, disadvantaged, and powerless. Alastair Pennycook (1995) says that linguistic imperialism can occur when English becomes a gateway to education, employment, business opportunities, and popular culture and where indigenous languages and cultures are marginalised. Linguistic imperialism is an imposition or dominance of one language speakers on others through various ways, i.e. intellectually, culturally, politically, economically, and psychologically. In contemporary times, English is imposed and dominates through these tools over the vernacular students. According to Robert Henry Lawrence Phillipson (1992, p. 47):

English linguistic imperialism is the dominance of English is asserted maintained by the establishment and continuous reconstitution of structural and cultural inequalities between English and other languages. 
Guo and Beckett highlighted A. Suresh Canagarajah's argument that how English as a dominant language worldwide is forcing an unfamiliar pedagogical and social culture onto its learners, socio-psychologically, linguistically, and politically putting them in danger of losing their first languages, cultures, and identities and contributing to the devaluation of the local knowledge and cultures (2012, p. 59). It is clear that the worldwide spread of the English language is not a consequence of colonialism but it is also a tool of controlling the culture which shows the relationship between knowledge and power. Michel Foucault (1977) expressed it as 'knowledge is power'. He further states:

Knowledge linked to power, not only assumes the authority of 'the truth' but has the power to make itself true. All knowledge, once applied in the real world, has effects, and in that sense at least, 'becomes true'. Knowledge, once used to regulate the conduct of others, entails constraint, regulation and the disciplining of practice. Thus, there is no power relation without the correlative constitution of a field of knowledge, nor any knowledge that does not presuppose and constitute at the same time, power relations (Ibid, p. 27)

He believed that citizens of modern democracies are controlled less by the army, police, economic power, or a centralised, visible state apparatus than by pronouncements of expert discourse, which he calls 'regime of truth'. In which the expert discourse has a powerful impact on society as much through what it says as by what it does not say; as much by what is constructed as an object of investigation as by what is rejected as insignificant and then left beyond representation (Ryon, 2005, p. 57). The interaction of knowledge and power poses challenges on linguistically, economically, and socially marginalised sections of the society.

\section{Medium of Instruction and Linguicism}

The medium of instruction can be defined as 'the language through which any subject is taught or instructed by the teacher to the student in the classroom.' From elementary education to university level education most of the institutions in the country provide the education to people in their native language (First Language of the country) or in their mother tongue. In contrast to that multilingualism in India presents a different scenario, where government schools (or public schools) instruct students in their vernacular or mother tongue up to secondary level, that continues till college or graduation level. Whereas, students from different linguistic mediums get enrolment in Indian Institutes of Technology (IITs), All India Institute of Medical Sciences (AIIMS), central universities such as the University of Delhi and Hyderabad Central University, etc. where education is provided only through English medium.

Students' learning process through their mother tongue or regional language is more beneficial in comparison to another language. Ashok R. Kelkar argues that the 'own language' learning has 'beneficial effect on other language learning and teaching.' If students attain education continuously in their own language their power of understanding, confidence level, and positivity never goes down. Such students are mentally and psychologically very strong. To substantiate this argument Seemita Mohanty cited Jim Cummins' observation that 'to reject a child's language in the school is to reject the child' (2017, p. 31). The following news report reflects how language affects individual life. A Dalit student from a central university 'dropped out 
of the Masters programme, when he was yelled at during his viva for English course and told to go read Agatha Christie. "There is no one to provide help here, and it is shameful for our lack of language skills to be exposed here," he had mentioned in his note (Kartikeyan, 2017).

\section{Linguistic Discrimination or Linguicism in Indian Universities}

Discrimination is an unequal treatment or deferential behaviour towards a particular targeted individual or group, because of their belongingness in the educational institutions. Discrimination based on language is known as linguistic discrimination or Linguicism. The Term 'Linguicism' was coined by prominent linguistic scholar Tove Skutnabb-Kangas in the 1980s. According to her, linguicism is ideologies, structures and practices which are used to legitimate, effectuate, regulate and reproduce an unequal division of power and resources (both material and immaterial) between groups which are defined on the basis of language' (Skutnabb-Kangas, 2000, p. 30). It plays a decisive role in who uses which language for educational purpose and that determines the groups' 'linguistic human right. This right is related with culture and identity. The mother tongue is inherently related to human mind and body. The imposition of one language over the other language in the society through cultural and linguistic nationalism is a process of the hegemony of language. This hegemonic language pushed the other languages to the corner leading to violation of the linguistic rights of the individual, and groups in society. The United Nations in its Human Development Report (United Nations Development Program 2004, p. 33) emphasized that language is a major factor for cultural liberty and human development and argued that:

Language is often a key element of an individual's cultural identity. Limitations on people's ability to use their mother tongue - and limited facility in speaking the dominant or official national language-can exclude people from education, political life and access to justice. There is no more powerful means of 'encouraging' individuals to assimilate to a dominant culture than having the economic, social and political returns stacked against their mother tongue. Such assimilation is not freely chosen if the choice is between one's mother tongue and one's future.

In the context of Indian universities, linguistic imperialism is exercised by the Englishmedium pedagogy, the students, and faculties. It is creating a knowledge and power relations binary between English-medium and other vernacular-medium groups. The domination and hegemony of the English language, directly and indirectly, has been supported by the government through educational institutions and their official policies and programmes. Consequently, minority language medium students are suffering an inferiority complex and consequently losing their confidence. Most of the academic resources are available only in English. This domination negatively affects the learner's psychology. It leads to the violation of the linguistic right of students and teachers in the institutions. According to Skutnabb-Kangas (1999, p. 58):

Everybody, not just privileged elites or poor minorities, needs to be fluent and literate in at least two languages, preferably more. Everybody, not just minorities, needs to become aware of and acknowledge the importance of their 
ethnic and linguistic roots, in order to be able to develop, analyse, criticize, and reflect. Language rights for all are part of human rights. Language rights are prerequisite to many other human rights. Linguistic human rights in education are a prerequisite for the maintenance of diversity in the world that we are all responsible for.

Language is not just a matter of communication and speaking, but people have to share their ideas and thoughts. It is a major tool for every life activity of human beings. The majority of universities provide information regarding admission, curriculum, prospectus, advertisements, and other activities only in English. For example, University of Delhi, Jawaharlal Nehru University, and Hyderabad Central University have uploaded all the information only in English on their websites. ${ }^{5}$ Most of the students who come from regional medium backgrounds face problems to comprehend the information provided on their websites. Thus, the relation between power and knowledge begins from the very outset. The level of confidence slowly goes down; the inferiority complex starts sinking in from the entry point itself.

As Dua (1994, p. 5) cites Haugen that, the imposition of the (Language of Wider Communication) LWC for international advantage 'is disruptive of the life pattern, leaving people uprooted, lonely, aggressive and unsocial.' Social justice cannot be achieved by ignoring indigenous or vernacular language medium groups when they are facing language deprivation and become marginalized.

It is essential to examine why English is imposed in various ways as a matter of link language. Who is implementing the English language and what is the purpose of it? Language domination has been beneficial only for the English-speaking elites. They are exercising power on vernacular speakers through a knowledge system because it is widely influenced and in the clutch of the English language. S. M. Shannon (1995) argues that hegemony is part of the working process of society. A balance of power exists in all relationships because as Foucault argued like Gramsci power is not possessed by an individual, group, or their ideas - it is exercised. Therefore, Hans Raj Dua argues that just as communication at the international level concerns only a minority, the relevance and justification of pan-Indian communication is projected by only a few who want to retain their power and hegemony through the usage of English. Consequently, they adopt the dominant language and try to avoid their own language in order to gain a higher status. The significant relationship between language and ideology mentioned by Hans Raj Dua which shows that Language for wider Communication cannot be considered an exception to this:

[L]anguage is politically important because of its ideological power-its meanings shape our perceptions and our experience of the world. Our consciousness is formed by the language we encounter, when and where we encounter them. These relationships are possible because language actually constructs places for 'I', 'me,' and 'you' within the symbolic world it signifies. We become social subjects as we enter culture. We enter culture by learning language. (Dua, 1994, p. 9-10)

Therefore, it is clear that language, culture, and society are related to each other. The human mind imagines in its mother tongue and expresses its imagination through

${ }^{5}$ The basic details about the universities are available in Hindi but information regarding upcoming events such as admission and its procedure, curriculum, notifications etc. is available only in English. 
it. However, the elite status of the English language creates a line of demarcation between educational societies. Furthermore, the purpose of education is to create skilled labor, not for Dewey's aim of education. Now, education aims to enhance individual conditions only. But Dewey emphasised that educated individual needs to work for societal upliftment also $(2014$, p. 9). Nevertheless, language is also hierarchal in nature similar to the caste system in India. Correspondingly, vernacular-medium students are intellectually oppressed primarily in the higher educational institutions. Their ideology, mind, and psychology are controlled by the English-knowing people, teachers, and students. For example, vernacular-medium students are compelled to read English sources and write their answers in their language. They have to struggle a lot in understanding the theoretical concepts in English. Consequently, there is an identity crisis for a vernacular-medium scholar because of the dominance of the English language. Therefore, most of the vernacular-medium students try to convert their medium for academic success.

In this regard, Paulo Freire (2005) argues that education is thus an act of depositing, in which students are the depositories and the teachers are depositors. Instead of communicating, the teacher issues communiqués and makes deposits which the students patiently receive, memorize, and repeat. This is the banking concept of education, in which the scope of action allowed to the students extends only as far as receiving, filing, and storing the deposits. Vernacular-medium students struggle to understand English (meaning and grammar) and after that, they attempt to understand the concepts of their subjects. The process of learning and language shifting creates disinterest in knowing and acquiring knowledge from the subjects. A vernacularmedium student spends much time to understand the subjects and secure passing marks, which never helps in further study. The examination system and evaluation system is also unfair and unjustifiable because most of the evaluators assume that vernacularmedium students are not laborious and they do not have the ability to explain better in comparison to English-medium students. It happens because of the increasing importance of English. Linguicism can be seen when the teacher stigmatises the student because of vernacular language usage. A consequence of stigmatisation leads to language discrimination which is an unequal detachment of power and resources. Robert Phillipson mentioned Ghana's sociolinguist, Gilbert Ansre, who describes linguistic imperialism as:

The phenomenon in which the minds and lives of the speakers of a language are dominated by another language to the point where they believe that they can and should use only that foreign language when it comes to transactions dealing with the more advanced aspects of life such as education, philosophy, literature, governments the administration of justice, etc.... Linguistic imperialism has a subtle way of warping the minds, attitudes, and aspirations of even the most noble in a society and of preventing him from appreciating and realizing the full potentialities of the indigenous language (2011, p. 56).

Ansre's, analysis of linguistic imperialism is relevant here; it is the power that allows to English-speaking groups to dominate the Hindi-speaking groups in educational institutions and political spheres. Gradually even English has maintained its elitist status in Indian society. Every language has its own social, political, emotional, and psychological value. Knowing a language is not a concern, but oppression and 
suppression of other vernacular mediums are violations of their linguistic spaces. Consequently, these oppressed groups are affected by negative experiences and are gripped with inferiority complex, stigmatised excluded, unconfident, humiliated, lonely, etc., and sometimes it leads to suicide. Therefore, linguicism is not just about discrimination but is the violation of human existence. It gives the English-medium group better access to resources and for other vernacular language an unavoidable disadvantage. Vernacular-medium groups are excluded not just educationally but also, socially and economically. So, it needs to maintain the Indian multilingual status in education and other domains of the society at the policy, institutional, and other spaces. According to British Broadcasting Corporation journalist Soutik Biswas (2016):

Many Dalit students who get into colleges and universities through affirmative action quotas - restorative justice for centuries of historical wrongs against the community - come to campuses with deficiencies in education, including a feeble command over the English language. Most of them are first generation graduates, come from poor families - like Mr Vemula, born of a father who works as a security guard and a mother who's a tailor - and often struggle to fit in.

Ratan Lal, who teaches at University of Delhi's Hindu College, pointed out that the ability of reading and writing in English represents knowledge itself. This linguistic hegemony becomes a basis of systemic discrimination in higher education leading to the exclusion of those who are not able to express themselves in this language. This inability, however, does not mean that the students lack merit because merit is after all a social construct. What is needed is for universities to provide a space where minds can question freely and grow, irrespective of linguistic proficiency (The Wire, 2017). A student from Rajasthan enrolled in All India Institute in Medical Sciences committed suicide on March 4, 2012 because of language inability. According to his batchmate

Anil was a brilliant and hardworking student. He had made it to the AIIMS studying at a Hindi medium government school in his village. He faced difficulty in following lectures in English at AIIMS and thus failed in all three papers in the annual exam. He cleared one of the papers in the second attempt, but the weightage for internal exams in the final result was increased after the declaration of the result and he again failed in all three papers (The Hindu, 2016).

\section{Conclusion}

Being a researcher, I have observed that the university spaces and classrooms are dominated by English-medium students. The majority of the students do not oppose the English, but simultaneously, they want to be treated equally in these spaces. The language stratification in the educational institutions creates a hierarchy among the students. Language hierarchy among the students is interlinked with the caste, class, and gender hierarchy. It was examined that most of the lower caste, class, and female students who come from vernacular-medium background opt for social science due to the feeling/guilt and inefficiency in the English language. This hierarchy creates 
a power relation between vernacular-medium students and English-medium teachers and students inside and outside the classroom leading to the students' self-exclusion from peer groups, classroom participation, and engagement in various activities inside and outside the classroom. The self-exclusion prevents them from acquiring knowledge equally in this space. It is observed that those students continuously face language discrimination; they harbour thoughts of leaving/dropping out of the study programme, or a few students also thought about committing suicide. Therefore, it is necessary that government makes the provision of English-medium education along with mother tongue or native language to start from elementary education. The government should also establish a language laboratory in every higher educational institute so that vernacular-medium students or researchers can learn English as in these times of globalisation and modernisation, English has become an emancipatory language as well.

\section{References}

Ahmed, A., Zarif, T., \& T. (2013). The role of medium of instruction used in Pakistani classrooms. Interdisciplinary Journal of Contemporary Research in Business, 4(12), 609-613.

Biswas, Soutik. (2016, January 20). Why are India's Dalit students taking their lives?. BBC News.

Dasgupta, A. K. (1967). The language problem. Economic and Political Weekly, 2(28), 1253-58.

Dewey, J. (2014). Moral principles in education. New Delhi: Critical Quest.

Dua, Hans Raj. (1994). Hegemony of English. Mysore: Yashoda Publications.

Foucault, Michel. (1977). Discipline and punish: the birth of the prison (trans. A. Sheridan). London: Penguin Books.

Freire, Paulo. (2005). Pedagogy of the oppressed. New York: Continuum.

Gramsci, Antonio. (1985). Selections from the prison notebooks of Antonio Gramsci (trans. Q. Hoare and G. Nowell-Smith). New York: International Publishers.

Guo, Y., \& Beckett, G. (2012). A critical analysis of English language teaching in today's market economy in China. In K. Sung and R. Pederson (Eds.), Critical ELT practices in Asia: key issues, practices, and possibilities (Vol. 82, Transgressions: cultural studies and education, pp. 55-70). Rotterdam: Sense Publisher.

Indian Express. (2017, February 4). Ambedkar University survey: 76\% students from govt. schools face problems with English. Indian Express, Retrieved on February 9, 2017 from http://indianexpress.com/article/education/ambedkar-university-survey-76-students-fromgovt-schools-face-problems-with-english/

Karthikeyan, Divya. (2017, March 16). JNU student suicide: subtle and overt discrimination haunting young Dalits in Indian Colleges. Firstpost, Retrieved on July 26, 2017 from http:// www.firstpost.com/india/jnu-student-suicide-subtle-and-overt-discrimination-hauntingyoung-dalits-in-indian-colleges-3337346.html

Mohanthy, A. K. (2009). Multilingualism of the unequal and predicaments of education in India: mother tongue or other tongue?. In O. García, T. Skutnabb-Kangas and M. E. TorresGuzmán (Eds.), Imagining multilingual schools: languages in education and glocalization (pp. 262-283). New Delhi: Orient Longman Private Limited.

Mohanty, Seemita. (2017). Education in mother tongue: impact of multilingual education in Odisha. Economic and Political Weekly, 52(7), 31. 
Mustapha, Abolaji S. (2014). Linguistic hegemony of the English language in Nigeria. Íkala, Revista de Lenguaje y Cultura, 19(1), 59. Retrieved on February 9, 2017 from https:// aprendeenlinea.udea.edu.co/revistas/index.php/ikala/article/view/15315

Ngussa, Barak Manjale. (2017). Correlations between medium of instruction and interaction factors among teacher trainees: a case study of the University of Arusha-Musoma Centre, Tanzania. International Journal of Educational Policy Research and Review, 4(1), 4. Retrieved on February 3, 2017 from http://www.journalissues.org/IJEPRR/

Olagbaju, Oladotun O. and Akinsowon, Francis I. (2014). The use of Nigerian languages in formal education: challenges and solutions. Journal of Education and Practice, 5(9), 123. Retrieved on February 9, 2017 from http://www.iiste.org/Journals/index.php/JEP/article/ view/11874/12223

Pattanayak, D. P. (1984). Language policies in multilingual states. In A. B. Gonzalez (Ed.), Pangani: language planning, implementation and evaluation. Manila: Linguistic Society of Philippines.

Pennycook, Alastair. (2014). The cultural politics of English as an international language. New York: Routledge Taylor and Francis Group.

Pennycook, A. (1995). English in the world/The world in English. In J. W. Tollefson (Ed.), Power and inequality in language education (pp. 34-58). Cambridge: Cambridge University Press.

Phillipson, Robert. (2011). Linguistic Imperialism. Oxford: Oxford University Press.

Ryon, Dominique. (2005). Language death studies and local knowledge: the case of Cajun French. In A. Suresh Canagarajah (Ed.), Reclaiming the local in language policy and practice (pp. 55-72). New Jersey/ London: Lawrence Erlbaum Associates, Publishers.

Shannon, Sheila M. (1995). The hegemony of English: a case study of one bilingual classroom as a site of resistance. Linguistics and Education, 7(3), 176.

Skutnabb-Kangas, Tove. (1999). Education of minorities. In J. A. Fishman (Ed.), Handbook of language and ethnic identity (pp. 42-59). New York: Oxford University Press.

Skutnabb-Kangas, Tove. (2000). Linguistic genocide in education - or worldwide diversity and human rights?. Mahwah, New Jersey: Lawrence Erlbaum Associates, Publishers.

The Wire. (2017, March 15). Discrimination and exclusion continue to characterise the lives of Dalit Students. The Wire.

The Hindu. (2016, June 02). AIIMS student commits suicide. The Hindu.

Thorat, Sukhadeo. (2013). Higher education in India: emerging issues of diversity and discrimination, lecture at India China Institute October 28. Retrieved on December 10, 2020 from https://indiachinainstitute.org/wp-content/uploads/2013/10/Sukhadeo-Thorat Discussion-Paper_2013.pdf

United Nations Development Programme. (2004). Human development report 2004: cultural liberty in today's diverse world. New York: UNDP. 